\title{
Augmented Gel Dosage Form
}

National Cancer Institute

\section{Source}

National Cancer Institute. Augmented Gel Dosage Form. NCI Thesaurus. Code C91136.

A gel that is modified to enhance the release of active and/or inert ing redient(s). 